\title{
LESSON STUDY FOR PROFESSIONAL DEVELOPMENT OF ENGLISH LANGUAGE TEACHERS: KEY TAKEAWAYS FROM INTERNATIONAL PRACTICES
}

\section{Özgehan Uştuk irem Çomoğlu ${ }^{1}$}

${ }^{1}$ Dokuz Eylul University, Institute of Educational Sciences, Turkey

oustuk@balikesir.edu.tr

\begin{abstract}
Even though various professional development practices are provided for language teachers worldwide, these practices are still considered ineffective in addressing teachers' needs in their classrooms. The effectiveness of these practices is stalled when teachers do not actively engage in their professional development processes. When language teachers are not involved as active decision makers regarding their own professional development practices, the outcomes may not be as desirable as policymakers plan. Considering the deficiencies of the current language teacher professional development practices in Turkey, this paper provides a systematic review of lesson study as a professional development model for language teachers which promotes agency and reflective practice. Comparing the current practice of lesson study in Turkey to the international practices reported in the literature, this review suggests that lesson study has potential to support teacher professional development in the country in alignment with the educational visions of decision makers. Given the empowering dimension of lesson study model both in terms of content and form, it can be adopted as a model for effective and sustainable language teacher professional development.
\end{abstract}

\section{KEYWORDS}

Efficiency, English as a foreign language, lesson study, professional development, teacher

\section{HOW TO CITE}

Uştuk Ö., Çomoğlu İ. (2019) 'Lesson Study for professional development of English language teachers: Key takeaways from international practices', Journal on Efficiency and Responsibility in Education and Science, vol. 12, no. 2, pp. 41-50. http://dx.doi. org/10.7160/eriesj.2019.120202

\section{Article history}

Received

February 4, 2019

Received in revised form

May 19, 2019

Accepted

May 19, 2019

Available on-line

July 1, 2019

Highlights

- Lesson study has potential to support teacher professional development in alignment with the educational visions of decision makers.

- Lesson study practice can improve teachers' collaborative working culture and pedagogical literacy.

- Lesson study practice can be used to transform in-service teacher education both in terms of content and form.

\section{INTRODUCTION}

Constantly evolving demands and innovations in language learning and teaching have made career-long professional development of teachers an essential element for a sustainable language education policy. To support the professional development of language teachers, many training modules are provided in local, regional, national, and international contexts. However, the paradigmatic alignment of these attempts in terms of actual needs, form, and content is a matter of concern in this volatile world.
Khong and Saito (2014) put forward strong criticism with regard to conventional professional development practices. They problematized that such practices do not respond to the actual requisites of teaching and learning ecologies. Besides, they are one-off events and limited to a couple of days, which results in a minor or no influence on language teachers' beliefs and teaching philosophies.

Admittedly, the problems with regard to professional development for foreign language teachers, who teach English as an additional language to students' native language(s) in 
Turkey are the same as the global ones. Atay (2007) criticized professional development practices to be one-shot events with a top-down understanding rather than bottom-up. In an exploratory study, Korkmazgil and Seferoglu (2013) found that English as a foreign language (EFL) teachers' professional development practices are mostly in the form of in-service seminars and workshops about a particular topic decided by other decisionmakers rather than teachers. Furthermore, they asserted that the content of these events does not match EFL teachers' perceived needs. Similarly, Oruç-Ertürk, Gün, and Kaynardağ (2014) found that professional development practices for EFL teachers usually have not authentic and situated goals.

Within the scope of professional development practices in Turkey, Uysal (2012) evaluated a one-week in-service teacher training program for primary school language teachers offered by Ministry of National Education (MoNE) in Turkey to explore its effect on teachers' attitudes, knowledge-base and classroom practices. Findings indicated that although the teachers' attitudes towards the course are positive in general, the one-shot program disregards the contextual needs of teachers and has limitations especially in terms of its planning and evaluation phases. Similarly, Koç (2016) explored the views of 32 elementary English language teachers who have participated in various in-service teacher-training activities organized by MoNE. The majority of the participant teachers complained that the activities offered were not relevant to their needs. For effectiveness in teacher professional development, Koç proposed a model which incorporates the identification of teacher needs, distance learning mode, active learning, a collaboration between MoNE and Higher Education Council, and assessment of program effectiveness.

Findings in Koç's study (2016) are in alignment with DarlingHammond, Hyler and Gardner's (2017: v-vi) assertions regarding the key features of effective teacher professional development. According to them, effective teacher professional development practice is content focused, incorporates active learning, supports collaboration, uses models of effective practice, provides coaching and expert support, offers feedback and reflection, and is of sustained duration.

Diagnostic studies mentioned above demonstrate that the current teacher professional development models in Turkey do not incorporate all of these elements. Given the pitfalls of the current teacher development practices in the country, MoNE has taken action to update and regulate the teacher professional development issue. In a recent report by MoNE (2018), the improvement of professional competencies of foreign language teachers is underlined as one of the key actions to take. However, the question of "how to fulfil these actions" is still unearthed and of critical importance.

In tandem with this, the current study provides a review on a specific teacher professional development model, lesson $s t u d y$, and recommends it as an alternative to be considered in Turkey. Li and Wang (2018: 123) stated that rigorous literature reviews and the conclusions reached in them can serve as a basis for practitioners and policy-makers to make decisions of how to meet the needs of different stakeholders. Thus, in this paper, the authors discuss the state-of-the-art practice of lesson study with worldwide instances and problematize how it can be used to maintain a sustainable professional development model for language teachers in Turkey. This article is based on the doctoral dissertation of the first author.

\section{A brief introduction to lesson study}

Even though lesson study is not an old form of teacher professional development in the western world, according to Dotger (2015) the earliest practices date back to the second half of the 19th century in Japan. As a way for Japanese educators to enable teachers to study their teaching practice and investigate the transformative nature of collaboratively developed curricula (Baba, 2007), lesson study was introduced to the western educational domain in the 1990s with prolific scholars such as Stigler and Hiebert (1999) and Lewis (2004).

A systematic analysis of lesson study by Lewis (2000) framed the main characteristics of this model, which helped us to understand why lesson study is distinctive in form. She suggested that lesson study is a process-based model to scaffold teachers while they collaboratively plan a research lesson that is taught by one participant-teacher while others observe it. Moreover, they are planned collaboratively and address an educational goal or vision determined by participant teachers. The process is concluded with a discussion of the teaching practice (Lewis, 2000).

In more recent research, several models have been developed and used. One of them is Dudley's (2013) lesson study process, which starts with an initial meeting of the lesson study group. In this meeting, the group members decide what they want to improve regarding their teaching, and they plan the first research lesson jointly. When one of the group members teaches the research lesson in a target classroom, the other members observe pupils and may interview them after the lesson. Based on the data from interviews, observations, and teacher's reflections, the participants discuss the first research lesson and develop it to the second one. They follow a similar process until the group shares their findings regarding the whole process. In another practical model by Cajkler and Wood (2016a), a more recursive process is introduced. According to them, lesson study process starts by identifying a learning challenge in a specific educational context. Later the group members collaboratively plan a research lesson to address this challenge and one member teaches it while the others observe specifically focusing on student learning. After evaluating the research lesson by the help of feedback on student learning, the research lesson is revised for re-teaching. Cajkler and Wood (2016a) proposed that the process ends by revisiting the learning challenge, to transform it if needed, and to proceed to the following lesson study cycle.

These two models are based on the transformative understanding that promotes teachers with an agency who are responsible for their own learning and teaching. That is the opposite of traditional teacher professional development practices in which teachers are passive learners receiving the 
content delivered by external experts. Research on lesson study shows that one of the most empowering influences of lesson study is to help the teachers develop agency in their teaching practice (Cajkler and Wood, 2016b; Lamb and Aldous, 2016). Another prominent result of the prior research is the promotion of reflective teaching practice with lesson study. This vein of research pointed out that lesson study model supports teachers' engagement in reflective practice (Olteanu, 2016; Ricks, 2011; Soto Gómez, Serván Núñez, and Caparros-Vida, 2016), which transforms teachers' understanding of student learning "because the issues they investigate are meaningful to their local teaching context" (Tasker, 2011: 221). Likewise, Johnson (2009) suggested that lesson study is an inquiry-based, teacher-directed, collaborative, and non-evaluative model that is grounded in actual teaching practices.

In the light of growing interest in transformative pedagogy and bridging research-pedagogy gap, studies reported lesson study experiences presented lesson study in terms of its efficiency. Sato and Loewen (2019) discussed communities of practice as one of the most feasible and efficient ways to establish transformative dialogue between researchers and teachers and teachers among themselves. Accordingly, Dudley (2014) reviewed that lesson study has potential to change the institutional norms and dynamics by creating communities of practice for the sake of safe and trustworthy environments for teachers to engage in research-driven knowledge and their peers' experiences. Similarly, Saito et al (2014) discussed lesson study as a part of sustainable school reform and proposed the term lesson study for learning community. According to the authors, lesson study's efficiency lies on its emphasis on long-term practice (as a cycle generally extends throughout weeks of implementation) and on effective professional learning of teachers; that is, professional development is continuing, social, and related to practice (Saito et al., 2014: 2).

On the other hand, research underlines several pitfalls for those who would like to implement lesson study. To illustrate, Gero (2015) argued that the implementers of lesson study should be well-aware of its bottom-up paradigm and avoid the temptation of a hierarchical version of it in which teaching challenges and goals are determined by administrators, mentors or policy-makers; whereas participant-teachers are "appointed" to follow the process. Furthermore, Bjuland and Mosvold (2015) highlighted the importance of an experienced lesson study facilitator to coach teachers throughout the process. They warned that inexperienced teachers or preservice teachers may have difficulty in observing student learning, and they can be lured to theoretical discussions rather than the practical basis of lesson study. Other very important factors that may "contaminate" the optimal result of lesson study are the lack of external administrative support (Lo, 2009; Tasker, 2011) and failure in giving constructive feedback (Cajkler, et al., 2013; Parks, 2009).

Despite the highlighted pitfalls, lesson study is potentially a collaborative (Cajkler et al., 2013; Cajkler, et al., 2015), inquiry-based (Johnson, 2009) and bottom-up (Dudley, 2013) model. As a model that was proposed for sustainable and efficient school reform (Saito et al, 2014), the authors reviewed lesson study within the context of foreign language teaching practice.

The authors specifically focused on lesson study in action; in that, how it has functioned in particular contexts may lead educational leaders who may include teachers, department chairs, administrators, and policy-makers all around the world. Accordingly, this paper brings the discussion to one step further than the question of "is lesson study effective in school reform?"; instead, it aims to review studies based on practice and discuss the implications of these practices for school reform in Turkey. Arguably, focusing on a specific context embedded in the wider context of lesson study applications is not a limitation for the current paper's transferability. This study is part of an on-going project that discusses the efficiency of lesson study at a foreign language instruction context in Turkey. By doing so, the conversation may transcend its context and influence similar reformist movements. Therefore, it is not only a review paper, but a start of a longer conversation for a sustainable and efficient teacher professional development policy.

In tandem with this background, the authors argue that this model can be discussed within the context of a recent reformist movement in Turkey that specifically aims to empower foreign language teachers through various reforms in both pre-service and in-service education (MoNE, 2018). By systematically analyzing the existing lesson study practice in Turkey with the lens of international practices, this paper provided implications for emancipating a lesson studyoriented language teacher professional development policy.

\section{MATERIALS AND METHODS}

A reviewing protocol was developed and followed to enact a systematic review. First, the authors used Scopus and ERIC databases with keywords "lesson study" (in-between quotation marks), "language", and "education". Scopus database was chosen since it includes International Journal for Lesson and Learning Studies, a major journal supported by World Association of Lesson Studies (WALS). The authors also decided to utilize ERIC as it is an authoritative database of indexed education literature. 21 articles on Scopus database and 64 peer-reviewed articles on ERIC database were reached on January, 22, 2019. Second, the authors introduced a set of inclusion criteria to find the relevant international research among 85 articles reached in total. These criteria were as follows:

- Related to lesson study

- Reporting a lesson study practice (not a review article, book review, etc.)

- Related to foreign/second language teacher education/ professional development

- $\quad$ Peer-reviewed

- One if occurring on both databases

- Not conducted in the Turkish context

After all, criteria were introduced, 11 studies were left for the focal review of international research published between 2011 and 2018. The table below summarizes the articles included in the international lesson study practice and research. 
Ceallaigh, Hourigan, and Leavy (2018)

Von Esch, Kavanagh
(2018)
(2018)

Cammarata and Haley
(2018)

\section{Nashruddin and} Nurrachman (2016)

Nami, Marandi, and Sotoudehnama (2016)

(n)

Csida and Mewald (2016) PrimarWebQuest in foreign language education

\begin{tabular}{ll}
\hline Cajkler and Wood (2016b) & $\begin{array}{l}\text { Mentors and student-teachers "lesson studying" in } \\
\text { initial teacher education }\end{array}$
\end{tabular}
Lesson study at the foreign language university level

Lander (2015) in Japan: Blended learning, raising awareness of technology in the classroom

Integrated content, language, and literacy instruction in a Canadian French immersion context: A professional development journey

The implementation of lesson study in English language learning: A case study

Computer-assisted language learning (CALL) teacher professional growth through lesson study practice: An investigation into EFL teachers' perceptions

Developing potentiality: Pre-service elementary teachers as learners of language immersion

Preparing mainstream classroom teachers of English learner students: Grounding practice-based designs for teacher learning in theories of adaptive expertise development

cor

Linguistically diverse English language learner (ELL) context in the USA / pre-service teacher education

Irish-medium immersion, content-based, elementary setting / pre-service teacher education language education / Japanese university context

\begin{tabular}{lll} 
& $\begin{array}{l}\text { Lander (2015) } \\
\text { technology in the classroom }\end{array}$ & language education / Japanese university context \\
Cajkler et al. (2013) & $\begin{array}{l}\text { Lesson study: Towards a collaborative approach to } \\
\text { learning in initial teacher education? }\end{array}$ & $\begin{array}{l}\text { Initial teacher education of pre-service teachers / } \\
\text { Modern languages program in the UK }\end{array}$ \\
\hline $\begin{array}{l}\text { Tan-Chia, Fang, and Chew } \\
\text { Ang (2013) }\end{array}$ & $\begin{array}{l}\text { Innovating the Singapore English language } \\
\text { curriculum through lesson study }\end{array}$ & $\begin{array}{l}\text { Lesson study as a way for K-12 teachers to } \\
\text { familiarize with recently introduced national } \\
\text { curriculum in Singapore }\end{array}$ \\
\hline Walker (2011) & How ,language-aware' are lesson studies in an East & $\begin{array}{l}\text { Learning study practice on content-based language } \\
\text { instruction in Hong Kong }\end{array}$
\end{tabular}

Table 1: International studies included in the review

After the studies shown in Table 1 were compiled for extensive review and analysis, the research related to lesson study practice in Turkey was searched. The last inclusion criterion was changed to "conducted in the Turkish context" and all criteria were introduced. In addition to Scopus and ERIC, another database TR Dizin was searched. TR Dizin is a database administered by Turkish Academic Network and Information Center, a governmental body that aims to support academic production in Turkey with information services and technologies. Arguably, TR Dizin is a way to search and find rigorous academic work published in the Turkish context but are not indexed in international databases. Search in TR Dizin resulted in 18 studies in addition to the earlier 85 studies from Scopus and ERIC. In total, three studies have been reached as illustrated in Table 2.

\section{Author(s)/Year}

Coskun (2017)

Yüzbaşıŏlu and Babadoğan (2016)

Demirbulak (2011)

\section{Title}

The application of lesson study in teaching English as a foreign language

Recommendations of participating teachers on the application of lesson study in Turkey

Training English language student teachers to become teacher-researchers
French immersion classes in Canada / 6th-12th grade teachers' professional development

Teaching English as a foreign language (EFL) / High school teacher in Indonesia

Professional development in CALL / Iranian context

Professional development in CALL / Austrian context

Initial teacher education of pre-service teachers / Modern languages program in the UK

Blended learning and technology use in foreign instruction in Hong Kong

\section{Table 2: Studies conducted in Turkey and included in the review \\ Table 2: Studies conducted in Turkey and included in the review}

Lesson study practice at a tertiary level institute.

$\mathrm{K}-12$ context, in various school districts in an urban area.

Initial teacher education at a university context, training teacher-researchers

(2336-2375 $1803-1617$




\section{RESULTS}

\section{International research}

In this section, studies that are eligible according to our review criteria are presented in a summative way. Firstly, Ceallaigh, Hourigan, and Leavy (2018) conducted their study in an Irishmedium content-based instructional setting. They utilized lesson study to design mathematics lessons in a second language and content integration program in the elementary school context. With a qualitative case study design, they investigated the issue of how pre-service teachers can get ready by the lesson study model. The authors discussed that this "integrated mindset" supported teachers to be more language-attentive and the participants' awareness towards of the role of language use in content-based instruction increased. They suggested that lesson study provided an initial teacher education space that helped pre-service teachers balance content and language in immersion settings.

Secondly, Von Esch and Kavanagh (2018) investigated the efficiency of a modified lesson study practice that they called EL/Math Studio. Drawing on lesson study model, they analyzed qualitative data from teachers working in second and third-grade classrooms composed of learners with linguistically diverse backgrounds in the USA context. Their analysis demonstrated that elementary teachers working with ELLs had problems of practice in terms of teacher language, comprehensible input, lesson planning, and explaining content knowledge and concepts. In the dialogic reflections structured by their Studio model, the participant teachers engaged in the problems they experienced in a reflective and scaffolded way. The structure of this model gave opportunities for them to develop their expertise by drawing on their existing capital of professional knowledge as a group, analyzing direct data from students. The authors observed that this practice-based, situated teacher education model helped teachers integrate language and content, identify instructional problems, and design solutions for them sustainably.

Another prominent study by Cammarata and Haley (2018) also pointed out the use of lesson study in terms of integrating content, language and literacy instruction in a French immersion context in Canada. In a longitudinal single case study design, they worked with Canadian teachers working in 6th-12th grades, seeking to empower them in terms of developing their curriculum planning skills by the use of lesson study as a developmental model. They discussed that collaborative lesson and curriculum planning in lesson study model helped the participants frame their existing knowledge and associate it with their actual teaching contexts although they initially had difficulty figuring out what language and literacy components to focus on while planning content-based lessons. The authors also provided evidence of the collaborative model's potential for maximizing teacher learning. The collaborative nature of the lesson study model aligned with learning theories like situated learning and communities of practice. On the other hand, Cammarata and Haley (2018) underlined a debilitating drawback due to the gap between what was planned by teachers and what was accomplished. Even though they stated that this gap got closer at the end of the research project that lasted one and a half year, the difficulty in changing teacher beliefs was highlighted.

Within the context of learning study, which is a teacher professional model that is very similar to lesson study, a study by Walker (2011) in Hong Kong provided similar results. The authors included this learning study-oriented piece of research in our review, considering that both learning and lesson study models are based on the idea of teachers paying extensive focus on student learning while following a recursive and collaborative practice (Wood, 2017). Walker (2011) reported that her learning study practice demonstrated evidence for more "language-aware" science teachers and empowered these teachers by making them feel more competent in a contentbased education context in.

Another study from the Indonesian context authored by Nashruddin and Nurrachman (2016) investigated the lesson study model in a case study design in teaching EFL at high school context. Drawing attention to the inclusive characteristic of the model, they suggested that inclusion of all ideas while co-developing lessons play an important role in the success of this model. They also proposed that focusing on student learning is of critical importance while observing the research lessons as well as reflecting on them.

Fifth, Nami, Marandi, and Sotoudehnama (2016) authored an article investigating the professional development of EFL teachers in CALL practices within the lesson study model in Iran. They analyzed the phases of the lesson study cycle implemented in the practice they investigated. As for the collaborative lesson planning phase, the results revealed that Iranian teachers had different opinions while evaluating their experience in the collaborative lesson planning phase in the model. The authors believed that this lack of consensus may have been due to the individualistic working culture in the country. Second, the participant teachers found implementing phase effective for their CALL professional development due to "direct engagement in the sustained teaching with technology based on the lesson plan they had developed" (Nami, Marandi, and Sotoudehnama, 2016: 671). Similarly, the observation phase was also valued by the participants as it enhanced their technological pedagogical knowledge. Last, the content of various types of peer-feedback was analyzed. The authors observed that the participants had occasional difficulties in providing negative feedback to their peers, which was associated with cultural aspects in the study.

Similar to the previous article, Csida and Mewald (2016) conducted a CALL professional development study in the Austrian context. In order to identify the skills required to work successfully on an instructional platform called PrimarWebQuest, they analysed how the participants acquired needed strategies and how their autonomy evolved in the process. Focusing primarily on the effectiveness of this platform rather than lesson study oriented professional development, the authors valued the use of lesson study as an effective way to refine teachers' lesson planning skills with regard to a specific instructional platform that is new to them.

Another CALL-related study was conducted by Lander (2015) at a university level foreign language teaching setting in the Japanese context. Based on a theoretical framework informed by 
blended learning and learner autonomy, the author investigated the effect of technology on academic achievement and student attitudes. Lesson study was used as a model to aid teachers and learners to reach improved achievement through online technology. Results indicated that lesson study practice can be useful in introducing new techniques and approaches as long as it is implemented effectively. Especially the communicational framework that is fostered by the lesson study model can make transformative professional development for language teachers who are expected to keep up with evolving innovations in education.

In the next study, Cajkler and Wood (2016b) reported the relationship between mentors and pre-service teachers in a lesson study experience in modern languages in the UK. Investigation of learning outcomes of both mentors and preservice teachers suggested that they benefited from reflective practice led by the structure of the lesson study model. The participants also discussed that their knowledge about learning and collaborative teaching increased and they developed a "pedagogic literacy", which refers to sustainable professional development through a continuum (Cajkler and Wood, 2016b: 94). Another study by Cajkler et al. (2013) conducted in a similar context explored the collaborative aspect of lesson study for pre-service teachers and their mentors. They used communities of practice framework to have a better understanding of lesson study experience for the stakeholders. Findings indicated that the lesson study model supported the professional development of not only pre-service teachers but also of all stakeholders including the experienced and veteran mentors and teachers.

In the Singaporean context, Tan-Chia, Fang, and Ang (2013) used lesson study as a scaffold and mediator while innovating a curriculum in English language education. They used lesson study as a tool to improve language teachers' professional capacity to carry out teaching strategies while teaching the revised version of English language teaching syllabi in Singapore. In their mixed-methods analysis, they focused extensively on the links between lesson study practice and delivery of national curriculum. The findings demonstrated that lesson study was an effective way to link teachers' subject knowledge with the new curriculum content. By connecting theory to practice in a praxis-based model, lesson study provided a structure for teachers to map and implement their theoretical knowledge. It was also reported in the study that the participant teachers' mindset shifted, in that, with the exclusive focus on learning in lesson study rather than teaching, teachers were able to abandon teacher-centric view and practices and develop an understanding of teacher who leads and facilitates learners, as projected in the new national policy.

\section{Research in the Turkish context}

Unfortunately, lesson study has not been acknowledged by language teachers, teacher educators, and administrators in Turkey, as the number of studies that reported prior practice suggests. Even though studies within the context of school subjects other than foreign/second language education are more common (e.g. Bozkurt and Yetkin-Özdemir, 2018), there were still a number of studies eligible for our review criteria.
The first study was conducted by Coskun (2017) in a context of tertiary level ELT teaching at a preparatory program. The study investigated how lesson study practice influenced EFL instruction and the professional development of three EFL instructors. Coskun asserted that observing student learning in the classroom helped EFL instructors to become more aware of problems emerging in teaching practice and show agency to solve these problems. Revising research lessons to overcome problems regarding student learning aided the participants to increase their pedagogical knowledge by learning more about classroom dynamics and learners. However, a critical concern was underlined about convincing more EFL instructors to engage in lesson study oriented professional development. Due to the existing workload at tertiary level language preparation contexts in Turkey, Coskun (2017) suggested taking precautions to maintain teacher commitment in lesson study practice. Another challenge reported by the author was Turkish EFL instructors' lack of observation experience. His case study provided diagnostic points to take into consideration in conducting effective lesson study practice in the Turkish context.

Within the Turkish context, Yüzbaşığlu and Babadoğan's experience (2016) highlighted lesson study as a professional development model based on constructivist teacher learning. The data were collected from socio-economically diverse school districts in a large city in Turkey. The findings showed that lesson study practice improved teacher learning, led to improved communication skills, efficiency and provided an opportunity for interaction and exchange of professional ideas. The participants were positive about lesson study as a professional development model and complained about the one-off professional development seminars provided at the beginning or end of the academic year. On the other hand, the participants asserted their concern about the sustainability of lesson study and the amount of time required in order for language teachers to integrate it into their daily teaching practice.

Demirbulak's (2011) study gave a practical instance from initial teacher education in the Turkish context. Demirbulak investigated the effects of lesson study model in training EFL teacher-researchers. In order for the pre-service teacher participants to develop their skills of planning English for Specific Purposes (ESP) lessons, the participants went through micro-teaching structured by lesson study model, and they were asked to generate a research focus and research agenda based on this experience. The findings gave evidence of increased teacher awareness and reflexivity. Engaging in reflective practice structured by lesson study supported the participants to design and revise research lessons with a critical agenda.

\section{DISCUSSION}

Drawing on the systematic review of the lesson study practices worldwide, this study aimed to highlight the potential of lesson study model to support language teacher professional development in Turkey. Our intention was to problematize the prospective affordances of lesson study for issues related to language teacher professional development in the country. 


\section{Potential of lesson study to prepare teachers for content-based language education}

International review of research concerning lesson study highlights the potential of lesson study to empower contentbased language education such as immersion classes in the Republic of Ireland (Ceallaigh, Hourigan and Leavy, 2018) and Canada (Cammarata and Haley, 2018) or ELLs in the USA (Von Esch and Kavanagh, 2018). The authors clearly demonstrated that lesson study's structure which allows a group of teachers to work specifically on student learning in a specific research lesson provides a recursive process to observe, revise, and develop this lesson collaboratively. This process supports teachers to counterbalance content and language so that more language-aware teachers (Walker, 2011) or communities of practice on content-based teachers (Cammarata and Haley, 2018) can emerge.

Even though it is not as common as in the European Union, content and language integrated learning (CLIL) practices do exist in Turkey, mostly in private institutions (Tok and Aribas, 2008). Also, as clearly stated in the visionary statement of educational reform in Turkey, the policy-makers are planning to adopt an interdisciplinary approach to language learning integrating content areas like math, science, social sciences, and visual sciences with language so that learners can actually use content-based language (MoNE, 2018: 68). Since the 20172018 academic year, the policy has been undergoing a pilot study process across Turkey in the schools administering an intensive foreign language curriculum provided by MoNE. Although international research gives a number of lesson study practices all around the world with intensive content-based and immersion language education contexts as examples of "good" and "sustainable" practices, our review shows that Turkish lesson study practice in content-based language education in $\mathrm{K}-12$ contexts, which could be highly beneficial to realize the educational vision of 2023 in Turkey, has not been reported at all.

\section{Initial language teacher education can be revisited with lesson study}

Pre-service language teacher education, specifically the practicum period, was another aspect to underpin in some of the reviewed studies. Language teaching is exceptional as it requires teachers not only to know but also to perform in the language they teach so that there are particular challenges language teachers face (Mercer, 2018). In the pre-service language teacher education context in Turkey, several challenges have been reported such as lack of reflective practice and teacher reflexivity (Akcan, 2010; Tülüce and Çeçen, 2015), lack of experience to observe peers and/or to be observed by mentors/supervisors (Coskun, 2013), and lack of collaboration with peers and mentors (Merç, 2010; Eröz-Tuğa, 2013; Ceylan, Uştuk and Çomoğlu, 2017).

Considering the research reviewed, lesson study can be given as an alternative model to overcome those trajectories to a certain extent. To illustrate, Cajkler and Wood (2016b) suggested that the lesson study model promoted reflective practice both among pre-service teachers and their mentors in initial teacher education programs in the UK. Moreover, lesson study also functioned as a collaborative scaffold that supported pre-service teachers to explore the complexities of pedagogies and develop pedagogical literacy (Cajkler and Wood, 2016b: 95). Likewise, collaborative action as a result of lesson studyinformed initial teacher education was reported by Cajkler $e t$ al. (2013). They asserted that communities of practice helped preservice teachers to establish a link between their education, and practice and these communities of practice created pedagogical awareness both for pre-service teachers and their mentors.

Nevertheless, the authors do not propose lesson study as the "the ultimate solution" to problems of initial teacher education in Turkey because prior research also showed certain shortcomings of lesson study practice specifically in initial teacher education. In an extensive review by Larssen et al., (2018), the authors underlined two critical bottom-lines to consider in order to strengthen lesson study practice and research. First, the concept of "learning" should be very clear for all lesson study stakeholders. Therefore, forming a common ground in terms of teaching philosophies plays a critical role in the use of lesson study in initial teacher education in which pre-service teachers typically lack in pedagogical experience as a teacher. The second point they highlighted was that pre-service teachers need to better understand classroom observation practice. Within the Turkish context, observation both in terms of to observe and to be observed is a problem (Merç, 2010). Especially, mentor observation as an anxiety provoker for EFL teachers in Turkey has been reported (Aydin, 2016). Notwithstanding the problems, observing peers (Cajkler and Wood, 2016b) and mentor observation and feedback (Merç, 2010) are among key strategies in teacher education. Also, Zhang, Yuan and Liao (2018) highlighted that teachers engaging in lesson study benefit from observing research lessons greatly even though they are not the one teaching.

In the in-service context, it is also important to remember that assessment of what teachers learn from lesson study experience or their performance in it by their colleagues or administrators/ mentors can provoke negative feelings. Debilitating influence of power relations can be manifested by that kind of assessment (Zhang, Yuan and Liao, 2018). To avoid this, certain precautions should be taken. Therefore, the future research should focus on the use of lesson study model while also being careful about the takeaways of the experiences reported in the prior research.

\section{Fine-tuning in-service language teachers for policy changes and innovations with lesson study}

The efficiency of the lesson study model to prepare teaching professionals for educational innovations and policy changes have been discussed in international research of lesson study practice. Studies by Nami, Marandi and Sotoudehnama (2016), Csida and Mewald (2016), and Lander (2015) demonstrated how effective lesson study-oriented professional development can assist teachers to get familiar with and adopt technological innovations and to use them in their teaching practice. As suggested by Dikilitas (2015), professional development has changed in terms of both form and content due to the swift developments of the modern world. In the context of education, more inquiry-based professional development for teachers 
gained interest and momentum such as action research (Tanis and Dikilitas, 2018) and lesson study (Johnson, 2009; Tasker, 2011). In terms of introducing new technology to teachers, professional development programs in Turkey have mistakenly been detached from the actual teaching ecology (Korkmazgil and Seferoglu, 2013; Oruç-Ertürk, Gün, and Kaynardağ, 2014) making them top-down attempts to solve the problem, which is unlikely to succeed (Wyatt and Ončevska-Ager, 2016).

In tandem with Dikilitas' assertion (2015), prior studies show that lesson study is different than conventional professional development format both in content and form. For instance, Csida and Mewald (2016) problematized that the grading system of foreign language education results in a lax attitude of learners in Austria, which they argued is to be solved by promoting learner autonomy. Independent language learners actively engaging in tasks outside of the classrooms on virtual platforms like PrimarWebQuest was discussed as a solution (Csida and Mewald, 2016). However, a problem arose about how ready language teachers are to facilitate learners with this platform. In their instance, lesson study practice focused both on teachers' and learners' learning, and teachers developed themselves not only about the best ways to implement PrimarWebQuest but also to empower learners throughout lesson study.

Rather than being "trained" in educational innovation, language teachers need to situate the "content" of professional development activity that is meaningful to them. Moreover, the "form" of their action should be inquiry, practice, and processbased. Our review shows that lesson study has got the potential to fine-tune in-service teacher education in Turkey according to actual needs and to bring authenticity to teacher learning. Tan-Chia and colleagues' research (2013) in the Singaporean context supports our argument. In their study, the lesson study model helped teachers have a more skilful use of teaching strategies and formative assessment practices introduced by the current language curriculum.

MoNE's visionary report (2018: 67) asserted that language education in Turkey is planned to be supported by online and mobile technologies. Moreover, the content available at Egitim Bilisim Agi, an online platform that provides content and solutions for K-12 teachers, will be actively integrated into language education (MoNE, 2018: 69). In light of these visions, language teachers, teacher educators and administrators should problematize how ready they are to integrate technological innovations in their classroom practices. Prior research in the Turkish context referred to the technology as a serious stressor for teachers and a source of foreign language teaching anxiety (Aydin, 2016). Likewise, Carbová and Betáková (2013) pointed out teachers who do not participate in-service teacher education programs can feel alienated and overwhelmed by the fast development of technology professional development programs. Accordingly, lesson study practices for integrating technological innovations into teaching can be a prospective future direction for teacher education research in the country.

\section{CONCLUSION}

Our review focused on international research of lesson study practice and compared it with local practices reported in the context of foreign language teacher education in Turkey. Drawing on the educational reform envisioned by MoNE in Turkey, three major themes emerged. First, lesson study has a potential aiding EFL teacher in the K-12 context to integrate language and content in a balanced way provided that administrative support is ensured. Second, the lesson study model scaffolds initial language teacher education in that preservice teachers can combine their education with practice in a reflective way and can grow into reflexive practitioners through lesson study. Moreover, lesson study practice can improve their collaborative working culture and pedagogical literacy as long as shortcomings of the prior practices are taken into account. Last, lesson study practice can be used to transform in-service teacher education both in terms of content and form so that teachers can engage in and develop meaningful practices. Our review discussed international research reporting a number of examples of how lesson study helped language teachers adopt technology and innovations into their teaching practice.

Our primary aim with this review paper is to provide a research agenda informed with local realities in language teacher education. Based on the ongoing discussion about the gap between researchers and practitioners within the context of applied linguistics and foreign/second language education (Ellis, 2010; Sato \& Loewen, 2019), we reviewed practice-based research to synthesize takeaways in accordance with Turkey's 2023 Vision of Education and suggest that implementing lesson study practices in language teacher education can be one of the keys to success. On a broader perspective, desideratum for prospective research may include focusing on lesson study practices reported in the prior research and analyze them with a theoretical framework in the light of local practices and realities. Such "thinking allowed" papers indicating stances of researcher-practitioner collaborations in a particular local context can potentially create a praxis-based research agenda for the field of language teacher education.

\section{REFERENCES}

Aydin, S. (2016) 'A qualitative research on foreign language teaching anxiety', The Qualitative Report, vol. 21, no. 4, pp. 629-642.

Akcan, S. (2010) 'Watching teacher candidates watch themselves: Reflections on a practicum program in Turkey', Profile Issues in Teachers 'Professional Development, vol. 12, no. 1, pp. 33-45.
Atay, D. (2007) 'Teacher research for professional development', ELT Journal, vol. 62, no. 2, pp. 139-147. https://doi.org/10.1093/elt/ $\underline{\mathrm{cc} 1053}$

Baba, T. (2007) Japanese education and lesson study: An overview, in. Isoda, M., Stephens, M., Ohara, Y. and Miyakawa, T. (eds.) 
Japanese lesson study in mathematics: Its impact, diversity, and potential for educational improvement, Singapore: World Scientific Publishing Co.

Bjuland, R. and Mosvold, R. (2015) 'Lesson study in teacher education: Learning from a challenging case', Teaching and Teacher Education, vol. 52, pp. 83-90. https://doi.org/10.1016/j. tate.2015.09.005

Bozkurt, E. and Yetkin-Özdemir, I. E. (2018) 'Middle school mathematics teachers' reflection activities in the context of lesson study', International Journal of Instruction, vol. 11, no. 1, pp. 379-394. https://doi.org/10.12973/iji.2018.11126a

Cajkler, W. and Wood, P. (2016a) 'Adapting, lesson study' to investigate classroom pedagogy in initial teacher education: What student-teachers think', Cambridge Journal of Education, vol. 46, no. 1, pp. 1-18. https://doi.org/10.1080/030576 $\underline{4 X .2015 .1009363}$

Cajkler, W. and Wood, P. (2016b) 'Mentors and student-teachers "lesson studying" in initial teacher education', International Journal for Lesson and Learning Studies, vol. 5, no. 2, pp. 84-98. https://doi.org/10.1108/IJLLS-04-2015-0015

Cajkler, W., Wood, P., Norton, J. and Pedder, D. (2013) 'Lesson study: Towards a collaborative approach to learning in initial teacher education?', Cambridge Journal of Education, vol. 43, no. 4, pp. 537-554. https://doi.org/10.1080/0305764X.2013.834037

Cajkler, W., Wood, P., Norton, J. and Pedder, D. (2014) 'Lesson study as a vehicle for collaborative teacher learning in a secondary school', Professional Development in Education, vol. 40, no. 4, pp. 511-529. https://doi.org/10.1080/19415257.2013.866975

Cajkler, W., Wood, P., Norton, J., Pedder, D. and Xu, H. (2015) 'Teacher perspectives about lesson study in secondary school departments: A collaborative vehicle for professional learning and practice development', Research Papers in Education, vol. 30, no. 2, pp. 192-213. https://doi.org/10.1080/02671522.2014. $\underline{887139}$

Cammarata, L. and Haley, C. (2018) 'Integrated content, language, and literacy instruction in a Canadian French immersion context: A professional development journey', International Journal of Bilingual Education and Bilingualism, vol. 21, no. 3, pp. 332348. https://doi.org/10.1080/13670050.2017.1386617

Carbová, A. and Betáková, L. (2013) 'Developing technological pedagogical content knowledge of English language teachers', Journal on Efficiency and Responsibility in Education and Science, vol. 6, no. 4, pp. 203-217. https://doi.org/10.7160/ eriesj.2013.060401

Ceallaigh, T. J. Ó., Hourigan, M. and Leavy, A. (2018) 'Developing potentiality: Pre-service elementary teachers as learners of language immersion teaching', International Journal of Bilingual Education and Bilingualism, pp. 1-18. https://doi.org/10.1080/1 $\underline{3670050.2018 .1489779}$

Ceylan, E., Uştuk, Ö. and Çomoğlu, İ. (2017) 'The ELT practicum in Turkey: A meta-synthesis of 2008-2017 qualitative research', The Literacy Trek, vol. 3, no. 2, pp. 102-113.

Coskun, A. (2013) 'Stress in English language teaching practicum: the views of all stakeholders', Hacettepe University Journal of Education, vol. 28, no. 3, pp. 97-110.

Coskun, A. (2017) 'The Application of Lesson Study in Teaching English as a Foreign Language', Inönü Üniversitesi Eğitim Fakültesi Dergisi, vol. 18, no. 1, pp. 151-162. https://dx.doi. org/10.17679/inuefd.297845

Csida, S. and Mewald, C. (2016) 'PrimarWebQuest in foreign language education', International Journal for Lesson and
Learning Studies, vol. 5, no. 1, pp. 45-59. https://doi.org/10.1108/ IJLLS-09-2015-0029

Darling-Hammond, L., Hyler, M. E. and Gardner, M. (2017) Effective teacher professional development. Palo Alto, CA: Learning Policy Institute.

Demirbulak, D. (2011) 'Training English language student teachers to become teacher-researchers', The Second World Conference on Psychology, Counselling and Guidance - Conference Proceedings, Procedia-Social and Behavioral Sciences, vol. 30, pp. 491-496. https://doi.org/10.1016/j.sbspro.2011.10.096

Dikilitaş, K. (2015) Teacher researchers in action, in Dikilitaş, K., Smith, R. and Trotman, W. (eds.) Professional development through teacher research, UK: IATEFL.

Dotger, S. (2015) 'Methodological understandings from elementary science lesson study facilitation and research', Journal of Science Teacher Education, vol. 26, no. 4, pp. 349-369. https:// doi.org/10.1007/s10972-015-9427-2

Dudley, P. (2013) 'Teacher learning in lesson study: What interactionlevel discourse analysis revealed about how teachers utilised imagination, tacit knowledge of teaching and fresh evidence of pupils learning, to develop practice knowledge and so enhance their pupils' learning', Teaching and Teacher Education, vol. 34, pp. 107-121. https://doi.org/10.1016/j.tate.2013.04.006

Dudley, P. (2014) Lesson study: Professional learning for our time, New York: Routledge.

Ellis, R. (2010) 'Second language acquisition, teacher education and language pedagogy', Language Teaching, vol. 43, no. 2, pp. 182-201. https://doi-org.proxy1.cl.msu.edu/10.1017/ $\underline{\mathrm{S} 0261444809990139}$

Eröz-Tuga, B. (2013) 'Reflective feedback sessions using video recordings', ELT Journal, vol. 67, no. 2, pp. 175-183. https://doi. org/10.1093/elt/ccs081

Gero, G. (2015) 'The prospects of lesson study in the US: Teacher support and comfort within a district culture of control', International Journal for Lesson and Learning Studies, vol. 4, no. 1, pp. 7-25. https://doi.org/10.1108/IJLLS-02-2014-0007

Johnson, K. E. (2009) Second language teacher education: A Sociocultural perspective, New York: Routledge.

Khong, T. D. H. and Saito E. (2014) 'Challenges confronting teachers of English language learners', Educational Review, vol. 66, no. 2, pp. 210-225.

Koç, E. M. (2016) 'General investigation of the in-service training of English language teachers at elementary schools in Turkey', International Electronic Journal of Elementary Education, vol. 8, no. 3, pp. 455-466.

Korkmazgil, S. and Seferoğlu, G. (2013) 'Exploring non-native English teachers' professional development practices', Boğaziçi Üniversitesi Ë̆itim Dergisi, vol. 30, no. 1, pp. 1-10.

Lamb, P. and Aldous, D. (2016) 'Exploring the relationship between reflexivity and reflective practice through lesson study within initial teacher education', International Journal for Lesson and Learning Studies, vol. 5, no. 2, pp. 99-115. https://doi. org/10.1108/IJLLS-11-2015-0040

Lander, B. (2015) 'Lesson study at the foreign language university level in Japan: Blended learning, raising awareness of technology in the classroom', International Journal for Lesson and Learning Studies, vol. 4, no. 4, pp. 362-382. https://doi.org/10.1108/ IJLLS-02-2015-0007

Larssen, D. L. S., Cajkler, W., Mosvold, R., Bjuland, R., Helgevold, N., Fauskanger, J., Wood, P., Baldry, F., Jakobsen, A., Bugge, H. E., Næsheim-Bjørkvik, G. and Norton, J. (2018) 'A literature 
review of lesson study in initial teacher education: Perspectives about learning and observation', International Journal for Lesson and Learning Studies, vol. 7, no. 1, pp. 8-22. https://doi. org/10.1108/IJLLS-06-2017-0030

Lewis, C. (2000) 'Lesson study: The core of Japanese professional development', The Annual Meeting of the American Educational Research Association - Conference Proceedings, National Science Foundation, Washington, DC., pp. 1-47. Available at: https://files.eric.ed.gov/fulltext/ED444972.pdf

Lewis, C. (2004) 'Does lesson study have a future in the united states?', Journal of Social Science Education, vol. 3, no. 1, pp. 115-137. https://doi.org/10.4119/jsse-321

Li, S. and Wang, H. (2018) Traditional literature review and research synthesis, in Phakiti, A., De Costa, P. I., Plonsky, L. and Starfield S. (eds.) The Palgrave handbook of applied linguistics research, London: Palgrave Macmillan.

Lo, M. L. (2009) 'The development of the learning study approach in classroom research in Hong Kong', Educational Research Journal, vol. 24, no. 1, pp. 165-184.

Mercer, S. (2018) 'Psychology for language learning: Spare a thought for the teacher', Language Teaching, vol. 51, no. 4, pp. 504-525. https://doi.org/10.1017/S0261444817000258

Merç, A. (2010) 'Self-reported problems of pre-service EFL teachers throughout teaching practicum', Anadolu University Journal of Social Sciences, vol. 10, no. 2, pp. 199-226.

Ministry of National Education (MoNE) (2018) 2023 Eğitim Vizyonu. Ankara: Republic of Turkey Ministry of National Education. Available at: http://2023vizyonu.meb.gov.tr/doc/2023 EGITIM VIZYONU.pdf

Nami, F., Marandi, S. S. and Sotoudehnama E. (2016) 'CALL teacher professional growth through lesson study practice: An investigation into EFL teachers' perceptions', Computer Assisted Language Learning, vol. 29, no. 4, pp. 658-682. https://doi.org/1 $\underline{0.1080 / 09588221.2015 .1016439}$

Nashruddin, W. and Nurrachman, D. (2016) 'The implementation of lesson study in English language learning: A case study', Dinamika Ilmu, vol. 16, no. 2, pp. 169-179. http://dx.doi. org/10.21093/di.v16i2.356

Olteanu, C. (2016) 'Reflection and the object of learning', International Journal for Lesson and Learning Studies, vol. 5, no. 1, pp. 60-75. https://doi.org/10.1108/IJLLS-08-2015-0026

Oruç-Ertürk, N., Gün, B. and Kaynardağ, A. (2014) 'Türk öğretmenlerin mesleki gelişim algilarinin belirlenmesi', Celal Bayar Üniversitesi Sosyal Bilimler Dergisi, vol. 12, no. 4, pp. 19-33.

Parks, A. N. (2009) 'Collaborating about what? an instructor's look at preservice lesson study', Teacher Education Quarterly, vol. 36, no. 4, pp. 81-97.

Ricks, T. E. (2011) 'Process reflection during Japanese lesson study experiences by prospective secondary mathematics teachers', Journal of Mathematics Teacher Education, vol. 14, no. 4, pp. 251-267. https://doi.org/10.1007/s10857-010-9155-7

Saito, E., Murase, M., Tsukui, A. and Yeo, J. (2014) Lesson study for learning community: A guide to sustainable school reform, New York: Routledge.

Sato, M. and Loewen, S. (2019) 'Do teachers care about research?
The research-pedagogy dialogue', ELT Journal, vol. 73, no. 1, pp. 1-10. https://doi-org.proxy2.cl.msu.edu/10.1093/elt/ccy048

Soto Gómez, E., Serván Núñez, M. J. and Caparros-Vida, R. (2016) 'Learning to teach with lesson study: The practicum and the degree essay as the scenario for reflective and cooperative creation', International Journal for Lesson and Learning Studies, vol. 5, no. 2, pp. 116-129. https://doi.org/10.1108/IJLLS-12-2015-0042

Stigler, J. W. and Hiebert, J. (1999) The teaching gap: Best ideas from the world's teachers for improving education in the classroom, New York: The Free Press.

Tan-Chia, L., Fang, Y. and Chew-Ang, P. (2013) 'Innovating the Singapore English language curriculum through lesson study', International Journal for Lesson and Learning Studies, vol. 2, no. 3, pp. 256-280. https://doi.org/10.1108/IJLLS-03-2013-0017

Tanış, A. and Dikilitaş, K. (2018) 'Turkish EFL instructors' engagement in professional development', Eurasian Journal of Applied Linguistics, vol. 4, no. 1, pp. 27-47. https://dx.doi. org/10.32601/ejal.460628

Tasker, T. (2011) Teacher learning through LS: An activity theoretical approach toward professional development in the Czech Republic, in Johnson, K. E. and Golombek, P. R. (eds.) Research on second language teacher education: A sociocultural perspective on professional development, New York: Routledge.

Tok, H. and Arıbaş, S. (2008) 'Avrupa Birliğine uyum sürecinde yabanc1 dil öğretimi’, İnönü Üniversitesi Eğitim Fakültesi Dergisi, vol. 9, no. 15, pp. 205-229.

Tülüce, H. S. and Çeçen, S. (2016) 'Scrutinizing practicum for a more powerful teacher education: A longitudinal study with pre-service teachers', Educational Sciences: Theory and Practice, vol. 16, no. 1, pp. 127-151.https://doi.org/10.12738/estp.2016.1.0207

Uysal, H. H. (2012) 'Evaluation of an in-service training program for primary-school language teachers in Turkey', Australian Journal of Teacher Education, vol. 37, no. 7, pp. 14-29.

Von Esch, K. S. and Kavanagh, S. S. (2018) 'Preparing mainstream classroom teachers of English learner students: Grounding practice-based designs for teacher learning in theories of adaptive expertise development', Journal of Teacher Education, vol. 69, no. 3, pp. 239-251. https://doi.org/10.1177/0022487117717467

Walker, E. (2011) 'How ,language-aware' are lesson studies in an East Asian high school context?', Language and Education, vol. 25, no. 3, pp. 187-202. https://doi.org/10.1080/09500782.2011. $\underline{555557}$

Wood, K. (2017) 'Is there really any difference between lesson and learning study? Both focus on neriage', International Journal for Lesson and Learning Studies, vol. 6, no. 2, pp. 118-123. https:// doi.org/10.1108/IJLLS-02-2017-0008

Wyatt, M. and Ončevska-Ager, E. (2016) 'Teachers' cognitions regarding continuing professional development', ELT Journal, vol. 71, no. 2, pp. 171-185. https://doi.org/10.1093/elt/ccw059

Yüzbaşığlu, S. and Babadoğan, C. (2016) 'Recommendations of participating teachers on the application of lesson study in Turkey', Journal of Education and Future, vol. 9, pp. 101-122.

Zhang, H., Yuan, R. and Liao, W. (2018) 'EFL teacher development facilitated by lesson study: A Chinese perspective', TESOL Quarterly. vol. 53, no. 2, pp. 1-11. https://doi-org.proxy2.cl.msu. edu/10.1002/tesq.480 